University of Nebraska - Lincoln

DigitalCommons@University of Nebraska - Lincoln

7-2006

\title{
Working Hours in Japan: Who Is Time-Privileged?
}

Scott M. Fuess Jr.

University of Nebraska-Lincoln, SFUESS1@UNL.EDU

Follow this and additional works at: https://digitalcommons.unl.edu/econfacpub

Part of the Economics Commons

Fuess, Scott M. Jr., "Working Hours in Japan: Who Is Time-Privileged?" (2006). Economics Department Faculty Publications. 36.

https://digitalcommons.unl.edu/econfacpub/36

This Article is brought to you for free and open access by the Economics Department at DigitalCommons@University of Nebraska - Lincoln. It has been accepted for inclusion in Economics Department Faculty Publications by an authorized administrator of DigitalCommons@University of Nebraska - Lincoln. 


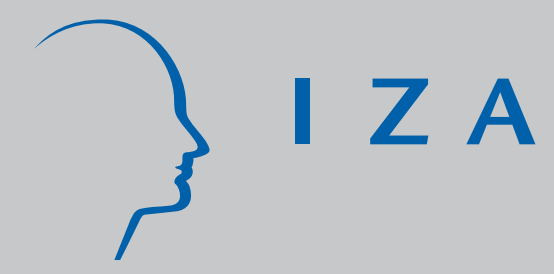

IZA DP No. 2195

Working Hours in J apan:

Who Is Time-Privileged?

Scott M. Fuess, J r.

July 2006 


\title{
Working Hours in Japan: Who Is Time-Privileged?
}

\author{
Scott M. Fuess, Jr. \\ University of Nebraska-Lincoln \\ and IZA Bonn
}
Discussion Paper No. 2195
July 2006

\author{
IZA \\ P.O. Box 7240 \\ 53072 Bonn \\ Germany \\ Phone: +49-228-3894-0 \\ Fax: +49-228-3894-180 \\ Email: iza@iza.org
}

\begin{abstract}
Any opinions expressed here are those of the author(s) and not those of the institute. Research disseminated by IZA may include views on policy, but the institute itself takes no institutional policy positions.

The Institute for the Study of Labor (IZA) in Bonn is a local and virtual international research center and a place of communication between science, politics and business. IZA is an independent nonprofit company supported by Deutsche Post World Net. The center is associated with the University of Bonn and offers a stimulating research environment through its research networks, research support, and visitors and doctoral programs. IZA engages in (i) original and internationally competitive research in all fields of labor economics, (ii) development of policy concepts, and (iii) dissemination of research results and concepts to the interested public.
\end{abstract}

IZA Discussion Papers often represent preliminary work and are circulated to encourage discussion. Citation of such a paper should account for its provisional character. A revised version may be available directly from the author. 


\section{ABSTRACT}

\section{Working Hours in Japan: Who Is Time-Privileged?*}

In the U.S. the relationship between hours worked and employee earnings has been reversed. Whereas the highest earners used to work the shortest hours, now they work the longest hours. This study examines whether such a reversal has occurred elsewhere, namely, Japan. Since the early 1990s the Japanese government has sought to transform the country into a "lifestyle superpower" by trying to encourage more daily time for leisure and less time on the job. Analyzing data for 1976-2003, it is clear that scheduled and actual working hours did indeed fall after 1990. During the early years of the sample, 1976-89, the highest earners also worked the shortest hours, that is, high income workers were timeprivileged. As working hours fell in the 1990s, the time privileges of the highest earners changed too. Specifically, the highest earners gained time advantages relative to the lowest earners but lost some advantages relative to the median.

JEL Classification: J22, J31, J40

Keywords: $\quad$ time allocation and labor supply, wage level and structure, country studies: Japan

Corresponding author:

Scott M. Fuess, Jr.

Department of Economics

College of Business Administration

University of Nebraska

P.O. Box 880489

Lincoln, NE 68588-0489

USA

E-mail: sfuess1@unl.edu

\footnotetext{
* I thank Ryan Gorka and Tristan Markwell for research assistance. Any remaining shortcomings are my responsibility.
} 


\section{Introduction}

In the United States the relationship between worker earnings and work times has changed over the past century. Costa (2000) has documented an important reversal. Between the 1890 s and the 1990s working times became more compressed. In the 1890s those with the highest hourly earnings worked fewer hours than the lowest paid. In the early 1970s differences in hours worked were negligible. But by 1991 workers with the highest hourly earnings also worked the longest hours. This reversal of the hours/pay relationship means that part of the recent increase in earnings inequality is due to differences in hours worked. Costa’s analysis raises an important question. Has the reversal of the hours/pay relationship been repeated elsewhere? As an economy develops, is it a matter of course that at first the longest hours will we be worked by the lowest earners? Do the highest earners eventually come to work the longest hours? These questions are relevant today for another industrialized country: Japan.

In Japan a person's identity is inextricably linked with his employer. ${ }^{1}$ Japan is famous for especially long working hours. The Japanese language even has a particular term for “death from overwork” (karoshi). Although Japan is nominally rich, its “empty affluence” has been controversial (for example, see McCormack, 1996). So it is no surprise that "quality of life” has become an important issue in the country. As noted by Leheny (2003, p. 107), the heart of the debate has been the infamous (ostensibly European) jibe that Japan is a nation of "workaholics living in rabbit hutches.”

Since the early 1990s the government has sought to transform the country into a "lifestyle superpower” by trying to encourage more daily time for enjoyment and less time on the job. ${ }^{2}$ For example, firms have been encouraged to adopt five-day weeks (dropping Saturday as a work

\footnotetext{
${ }^{1}$ Perspectives on how work shapes the lives of Japanese people can be found in the collection edited by Plath (1983).

${ }^{2}$ On the pursuit of leisure in Japan, see Leheny (2003), Linhart (1988), Linhart and Frühstück (1998), and Plath (1964).
} 
day). New public holidays have been established and Monday holidays have created three-day weekends. In 1994 the government announced a desire to reduce working hours across the country, setting a target of 150 working hours per month by 1996 . There also have been policies to encourage the building of museums, resorts, and theme parks.

In a related study, Fuess (2006) documents how daily leisure activities are linked to labor market conditions. Focusing on time surveys conducted between 1986 and 2001, he documents that shorter work schedules do encourage a more active leisure lifestyle. Despite considerable talk about becoming more leisure-oriented, have working times been cut, and if so, for whom? In Japan there appears to be a sense of widening income inequality. ${ }^{3}$ Can changes in the hours/pay relationship be invoked as a source of disparity?

Regular, full-time employees in Japan have annual contracts. Companies begin a new fiscal year on April 1, with employees’ monthly pay set for one year from this date. Labor contracts specify monthly pay. Working hours are also scheduled on a monthly basis. Do employees with the highest monthly earnings also work the shortest hours? In other words, are higher income workers also time-privileged? Perhaps higher incomes also mean longer working hours. In the drive to shorten working hours, how has the hours/pay nexus evolved?

Ever since 1976 Japan’s Ministry of Labour has reported information about earnings and working hours in each of the country’s 47 prefectures. The data distinguish between regularly scheduled hours per month and total hours worked (scheduled hours plus non-scheduled hours, that is, overtime work). The most recent figures are for $2003 .^{4}$

${ }^{3}$ For press accounts, see The Economist (2006) or The Japan Times (2001).

${ }^{4}$ In 2000 the Ministry of Labour became the Ministry of Health, Labour and Welfare. For convenience, I use the term "Ministry of Labour" throughout. Earnings and hours data are reported in the Year Book of Labour Statistics, Tokyo: Ministry of Labour. The data are from the Year Books for 1976-2003, respectively. Earnings (regular contractual monthly earnings) are reported in the table "Average Monthly Cash Earnings by Prefecture and Industry).” Contractual earnings include pay for scheduled work and non-scheduled work. Monthly working times (scheduled hours, total hours) are from the table “Average Monthly Working Hours by 
For 1976-2003 I measure the gaps between the longest and shortest working times and examine whether those gaps have changed over time. Because it is possible to stratify the highest- and lowest-paying prefectures in the economy, it is possible to analyze how work hours have varied for workers at different earnings levels. Specifically, I study the relationship between scheduled working hours and contractual earnings. Then accounting for non-scheduled work (overtime), I also examine the relationship between total working hours and contractual earnings.

During the first half of the sample, 1976-89, Japan’s economy experienced relatively brisk growth, averaging 4.0 percent per year. In the latter half of the 1980s Japan experienced an episode known as the "bubble economy." Speculative increases in asset and real estate prices stimulated an economy-wide binge of lending and spending. The speculative bubble burst in 1990 and Japan's economic growth slowed markedly in the early 1990s. For 1990-96 yearly economic growth fell to 2.3 percent. In the later 1990s the economy deteriorated, with slow growth giving way to stagnation and deflation. For 1997-2003 economic growth averaged a

paltry 0.9 percent. Given these developments, I consider the first half of the sample (1976-89) as years of a relatively "brisk" economy, the third quarter of the sample (1990-96) represents years of “slower growth,” and the fourth quarter (1997-2003) represents a "sluggish” era.

During the "brisk” years high-income employees were time-privileged. As working hours fell across Japan after 1990, time privileges changed too.

\section{Distribution of Work Time}

Consider first the case of regularly scheduled work hours per month, figures for which are reported in Table 1 (top panel). In 1976 the median across Japan’s 47 prefectures was 166.5 hours per month. The difference between the longest and shortest working deciles was 9.2

Prefecture and Industry.” In all cases, the figures are for establishments with 30 employees or more. 
hours, with little more than half of that gap (5.2 hours) occurring between the median and the shortest working decile. Scheduled hours were somewhat shorter for 1990, with the median dropping to 159.1.

The Japanese government set a goal that by 1996 working times would fall to 150 hours per month. Whether it was the government campaign to shorten work times, or a by-product of the decelerating economy, by 1997 median scheduled hours did indeed fall to 149.4 per month. By 2003 the median had dipped further, to 144.8 hours; moreover, even in the longest working decile scheduled hours dropped to 148.3.

Scheduled working times in 2003 were roughly 15 percent less than for 1976, but did not become noticeably more compressed. For 1976 the $\left(90^{\text {th }}-10^{\text {th }}\right)$ percentile gap is 9.2 hours; for 2003 the gap is even bigger, 10.1 hours. The difference between the longest working decile and the median is fairly stable ) 4.0 hours for $1976,3.5$ hours for 2003 . In contrast, the gap grows between the median and the shortest working decile, from 5.2 hours (1976) to 6.6 hours (2003). Throughout the sample period, most of the $\left(90^{\text {th }}-10^{\text {th }}\right)$ percentile gap is due to the disparity between the median and the shortest working decile; that is, scheduled hours fell more for the shortest working areas than the longest working ones.

Now consider the case of total hours worked monthly, scheduled hours plus nonscheduled (overtime) hours. The figures are reported in Table 1 (bottom panel). Like scheduled hours, there is a drop-off in total working hours after 1990. But accounting for overtime, actual working hours generally did not reach the goal of 150 hours per month. In 1976 the median across Japan was 177.1 total hours per month; it was still 174.1 hours in 1990. As of 1997, median scheduled hours may have fallen below 150, but total hours were still 161.5. ${ }^{5}$ By 2003 only the shortest working decile surpassed the 150 mark.

${ }^{5}$ Even in the shortest working decile, total work hours still exceeded 155. 
Focusing on actual hours worked, it is clear that working times in Japan have not been compressed; rather, gaps between the longest and shortest working deciles have grown. The $\left(90^{\text {th }}-10^{\text {th }}\right)$ percentile gap increases from 7.1 hours (1976) to 11.4 hours (2003). Again, most of that expansion is due to a widening gap between the median and the shortest working decile.

Although working hours have fallen across Japan, cuts have not been distributed uniformly. There is a widening gap between longer and shorter working prefectures. Working times have fallen more in the shorter working areas than elsewhere. Are the widening gaps in working times related to earnings? Are the time-privileged at the higher or lower end of the earnings distribution?

\section{Distribution of Scheduled Working Hours by Earnings}

To see if work patterns have varied by pay, I examine monthly working hours by earnings deciles. Consider the distribution of regularly scheduled monthly hours by contractual earnings per month, the results of which are presented in Table 2.

The highest paying prefectures (Aichi, Fukuoka, Tokyo) tend to have relatively large cities. The lower paying prefectures (like Akita, Gunma, Mie) tend to have relatively small, more rural-based populations.

In 1976 the highest earners exhibited the shortest scheduled working hours (160.9) and the lowest earners exhibited the longest scheduled hours (172.1). Consider the ratio of scheduled work time for the $90^{\text {th }}$ earnings percentile relative to the $10^{\text {th }}$ percentile. For $1976-89$ this ratio averages 0.952 , meaning top earners were scheduled to work roughly 5 percent less than bottom earners. This ratio is significantly less than $1(t=-21.21)$, so high-income workers were scheduled to be time-privileged compared to low-income workers.

The top earning workers also were time-privileged compared to the median. The hours ratio for the $90^{\text {th }}$ earnings percentile relative to the $50^{\text {th }}$ percentile averages 0.964 , which is significantly less than $1(t=-7.74)$. Median earners, in turn, were time-privileged compared to 
the $10^{\text {th }}$ percentile. The $50^{\text {th }} / 10^{\text {th }}$ hours ratio averages 0.987 , also significantly less than 1 $(t=-2.76)$.

For the "brisk" economy years, scheduled working hours varied by earnings. Employees in higher earning prefectures were scheduled to work less than in lower earning prefectures. As scheduled working hours fell in the 1990s, how were time privileges affected, if at all?

In 1990 the $90^{\text {th }}$ earnings percentile still experienced the shortest scheduled hours (151.6); the $10^{\text {th }}$ percentile still had the longest scheduled hours (162.7). For the "slower growth" years of $1990-96$, the $90^{\text {th }} / 10^{\text {th }}$ hours ratio falls to 0.920 . With the Japanese government pressing for shorter working hours, and with the economy decelerating, the highest earners were now scheduled to work 8 percent less than the lowest earners. As illustrated in Figure 1, in the early 1990s high-income employees were scheduled to become even more time-privileged.

The highest income employees also increased their time advantage relative to the median. For $1990-96$ the $90^{\text {th }} / 50^{\text {th }}$ ratio of scheduled hours falls to 0.940 . Top earners were scheduled to work 6 percent less than median earners. The median, in turn, became more timeprivileged compared to the lowest earners. The $50^{\text {th }} / 10^{\text {th }}$ ratio of scheduled hours falls to 0.979 .

As the campaign to shorten working times commenced in the early 1990s, the time advantages of higher income workers became more pronounced, which is illustrated in Figure 1. But the figure also shows that since the later 1990s the relative gains of upper income workers have been eroded somewhat.

For $1997-2003$ the $90^{\text {th }} / 10^{\text {th }}$ hours ratio climbs back to 0.948 , nearly identical to that observed for $1976-89$ (see Table 2 ). The $90^{\text {th }} / 50^{\text {th }}$ ratio rises to a new high of 0.971 . In contrast, the $50^{\text {th }} / 10^{\text {th }}$ ratio remains steady at 0.976 . During the "sluggish" years, scheduled monthly hours continued to fall across all earnings deciles, but the highest income employees lost some of their time advantages.

The figures reported in Table 2 indicate that higher income employees were scheduled to work less than lower income workers. But when it comes to total work hours ) that is, 
accounting for non-scheduled (overtime) work ) have high income employees really been timeprivileged?

\section{Distribution of Total Working Hours by Earnings}

Consider the distribution of total monthly working hours by earnings, shown in Table 3 . Accounting for overtime work, it is clear that the actual time privileges of upper income workers have not been as great as the scheduled advantages. In 1976 the highest earning employees worked the shortest hours (171.6). For 1976-89 the $90^{\text {th }} / 10^{\text {th }}$ hours ratio averages 0.974: in actuality the highest income workers worked roughly 21/2 percent fewer hours than the lowest earners. This ratio is significantly less than $1(t=-5.81)$, so high-income workers really were time-privileged.

Upper income employees also were time-privileged compared to the median. For 197689 the $90^{\text {th }} / 50^{\text {th }}$ ratio averages 0.978 , which is significantly less than $1(t=-4.20)$. Median

earners, however, worked virtually the same as those in the bottom decile, with the $50^{\text {th }} / 10^{\text {th }}$ ratio averaging 0.997 .

At first, employees in the top earnings decile worked less than those at the median or the bottom decile. For $1990-96$ the $90^{\text {th }} / 10^{\text {th }}$ hours ratio drops to 0.932: the highest income employees worked roughly 7 percent less than the lowest income workers. In the early 1990s the highest earning employees became even more time-privileged relative to the lowest earners, which is illustrated in Figure 2. The figure also shows that the top earners gained relative to the median, with the $90^{\text {th }} / 50^{\text {th }}$ ratio falling to 0.948 . In the 1990 s the time privileges of the top earnings decile nearly doubled relative to the median.

For the years $1997-2003$, Figure 2 shows a reversal of some time privileges. The $90^{\text {th }} / 10^{\text {th }}$ total hours ratio rises to 0.958 . More noteworthy, the $90^{\text {th }} / 50^{\text {th }}$ ratio climbs to a high of 0.982 ; the $50^{\text {th }} / 10^{\text {th }}$ ratio falls to a low of 0.976 . 
In the 1970s and 1980s the top earners enjoyed a $2^{1 / 2}$ percent time advantage compared to the median. In the early 1990s that time advantage nearly doubled. But by 2003 employees in the $90^{\text {th }}$ earnings percentile were working longer than those in the $50^{\text {th }}$ percentile (149.5 versus 149.1 hours). In 2003 it was the median earners who experienced a 21/2 percent time advantage relative to the lowest earners, with the top income employees working more than the median.

In one respect Japan's experience is similar to that of the U.S.: the highest income employees are losing some of their time privileges. Whereas the highest earners in Japan used to work the shortest hours, they now work as long as median earners. Unlike the U.S., Japan's highest earners still enjoy time privileges compared to the lowest earners.

\section{Factors Affecting Hours Ratios}

The hours/pay relationship changed after 1990. Were those changes related to the economy's "post-bubble” slowdown? Or did those changes occur regardless of economic conditions? To address these questions, I use a simple specification to try to identify factors that affect hours ratios. First I analyze scheduled hours and then consider the case of total work hours.

Specification. Suppose Ratio of Hours: $90^{\text {th }} / 10^{\text {th }}$ is the dependent variable, where it is defined as working hours (scheduled or total) of the top earnings decile relative to the lowest decile. Ratio of Hours may be affected by the overall state of the economy or that of the labor market. Representing changes in the overall economy, Economic Growth indicates the rate of real GDP expansion and Inflation Rate represents the rate of price changes. Focusing on the labor market, Productivity Growth indicates improvement in real output per employed person and Job Openings per Applicant reflects the relative ease of finding a job. ${ }^{6}$

${ }^{6}$ The Bureau of Labor Statistics presents real productivity (real GDP per employed person) for Japan in Table 3 of its July 26, 2004 report Comparative Real Gross Domestic Product Per Capita and Per Employed Person, Fourteen Countries, 1960-2003, Washington, DC: U.S. Department of Labor. The rate of inflation is approximated by the difference between 
Ratio of Hours may be changing over time regardless of economic conditions. Given the drive in the 1990s to shorten working hours, let $D 1990$ be a 0-1 indicator variable activated for 1990-2003. To focus on the most recent years, $D 1997$ is a 0-1 variable activated for 1997-2003. Thus, consider the regression equation:

$$
\begin{aligned}
& \text { Ratio of Hours: } 90^{\text {th }} / 10^{\text {th }}=\$ \$_{0}+\$ \text { Economic Growth }+\$ \text { Inflation Rate }+ \\
& \$ 3 \text { Job Openings per Applicant }+\$ \text { Productivity Growth }+ \\
& \$ 51990+\$ \$_{6} D 1997+, \text {, }
\end{aligned}
$$

where ${ }_{\mathrm{i}}$ is a random disturbance term. Also consider a similar regression equation for the dependent variable Ratio of Hours: $90^{\text {th }} / 50^{\text {th }}$, where the ratio is work hours (scheduled or total) of the top earnings decile relative to median earners.

Scheduled Hours. Focusing first on scheduled working times, the estimated equation for Ratio of Hours: $90^{\text {th }} / 10^{\text {th }}$ is presented in Table 4 (left column). Comparing the top and bottom earnings deciles, the ratio of scheduled hours is unrelated to the state of the economy or labor market. The estimated coefficients on Economic Growth, Inflation Rate, Job Openings for Applicant, and Productivity Growth are all insignificant. Nevertheless, the D1990 and D1997 coefficients are significant.

In the early years of the campaign to shorten working times, 1990-96, Ratio of Hours is 2.85 percentage points lower than for 1976-89. But for 1997-2003, the Ratio is only 0.62 percentage points lower than for 1976-89.

Instead of comparing the highest and lowest earners, consider an equation for Ratio of Hours: $90^{\text {th }} / 50^{\text {th }}$, shown in Table 4 (right column). Again, Ratio of Hours is unrelated to economic expansion, inflation, or job openings; the Ratio is marginally related to productivity gains. Controlling for economic conditions, Ratio of Hours is 2.70 percentage points lower for

nominal and real GDP growth. GDP data are from Annual Report on the Japanese Economy and Public Finance 2003-2004, Tokyo: Cabinet Office, Government of Japan, p. 387. The ratio of job openings-to-applicants can be found in the "Key Statistics" table of the Japan Statistical Yearbook 2005, Tokyo: Ministry of Internal Affairs and Communications. 
1990-96 than for 1976-89; Ratio is 0.22 points higher for 1997-2003 than for 1976-89. Compared to the median, the scheduled time-privileges of top earners increased in the early 1990s but those gains were later reversed.

Total Hours. Turning to total work hours, Table 5 (left column) reports the estimated equation for Ratio of Hours: $90^{\text {th }} / 10^{\text {th }}$. Economic conditions notwithstanding, since 1990 the top earners gained actual time privileges relative to the lowest earners. Ratio of Hours: $90^{\text {th }} / 10^{\text {th }}$ is 4.56 percentage points lower for 1990-2003 than for 1976-89.

The ratio of actual working hours is also affected by economic conditions. A growing economy means more work overall, especially for the lowest earners. Increasing economic growth by one point lowers Ratio of Hours by 1.76 percentage points.

Productivity improvements should bolster labor demand. Such boosts, evidently, are concentrated in the higher paying areas of the economy. Other things equal, improving productivity growth by one point increases Ratio of Hours: $90^{\text {th }} / 10^{\text {th }}$ by 1.97 percentage points. Productivity gains erode some of the time privileges of the highest earners. Similarly, the coefficient for Job Openings per Applicant is positive, but not statistically significant.

Instead of comparing the highest and lowest earners, consider an equation for Ratio of Hours: $90^{\text {th }} / 50^{\text {th }}$, presented in Table 5 (right column). Given the economy's performance, the D1990 and D1997 coefficients indicate that top earners gained time-privileges relative to median earners, but those gains were eroded in recent years. Other things equal, Ratio of Hours is 4.99 percentage points lower for 1990-96 than for 1976-89; for 1997-2003 it is 2.35 points lower than for 1976-89. Nevertheless, economic conditions negated those gains.

Ratio of Hours: $90^{\text {th }} / 50^{\text {th }}$ is directly related to Productivity Growth and Job Openings per Applicant and inversely related to Economic Growth and Inflation Rate. In the last five years of the sample period, Japan’s economy was characterized by deflation and sluggish growth, punctuated by a rebound in productivity growth and job openings. So despite an underlying trend for the highest earners to become even more time-privileged, recent economic conditions 
have eroded their advantage relative to median earners.

\section{Summary and Conclusions}

In a study of the U.S., Costa (2000) found a reversal in the hours/pay relationship. Before the 1970s, the lowest earning workers tended to work the longest. By the 1990s the

pattern was reversed, with the highest earners working the longest hours. Costa attributed part of the growing income disparity in the U.S. to this reversal of the hours/pay relationship. Are these results unique to the U.S., or can they be observed in other industrialized countries?

In the case of Japan, since the early 1990s there has been a drive to shorten working hours. Indeed, since the mid-1970s scheduled and actual working hours have fallen 10-15 percent. Given the drive to shorten working times, this study has examined how the hours/pay nexus has evolved over the 1976-2003 sample period.

Like the U.S., at first the highest earners in Japan worked the shortest hours, that is, the top earners were time-privileged. Unlike the U.S., as working times fell they did not become more compressed.

Compared to the lowest earnings decile, by 2003 employees in the top earnings decile had become even more time-privileged. This finding might shed some light on the perception of growing disparity in Japanese society. Recent press accounts have reported that income inequality in Japan has not become especially more pronounced (see Nakamura, 2005). Income distribution by age of household head has been steady (see The Economist, 2006). But if the highest earners (living in urban prefectures) have become even more time-privileged than the lowest earners (who live in more rural prefectures), that may foster a perception of growing inequality.

Relative to the lowest income areas, employees in the highest paying prefectures have become more time-privileged. But compared to the median, the time advantages of the top earners have been eroded. Regardless of the economy’s performance, for 1990-96 the highest 
earners gained time advantages relative to the median, but for 1997-2003 they lost some of those gains. Moreover, in the past few years economic conditions have combined to negate the time advantage of the highest earners relative to the median. So like the U.S., the time advantages of the highest earners are being reversed, at least relative to median earners. It remains to be seen whether or not the changes observed for 1997-2003 are sustained, whether there is a more definitive reversal in the hours/pay relationship. It is also important for future research to focus on other countries, to see if hours/pay reversals can be documented elsewhere. 


\section{References}

Costa, Dora. L. 2000. “The Wage and the Length of the Work Day: From the 1890s to 1991.” Journal of Labor Economics 18 (January): 156-181.

Economist, The. 2006. “The Rising Sun Leaves Some Japanese in the Shade.” June 20. Downloaded from <www.economist.com/world/asia/PrinterFriendly.cfm?story_id=7066297>.

Fuess, Scott M. Jr. 2006. “Leisure Time in Japan: How Much and for Whom?” IZA Discussion Paper 2002 (March). Bonn: Institute for the Study of Labor (IZA).

Japan Times, The. 2001. “Income Gap on Rise as Middle Class Deteriorates.” April 3.

Downloaded from <www.japantimes.co.jp/cgi-bin/makeprfy.p15?nn20010403c2.htm>.

Leheny, David. 2003. The Rules of Play: National Identity and the Shaping of Japanese Leisure. Ithaca: Cornell University Press.

Linhart, Sepp. 1988. “From Industrial to Postindustrial Society: Changes in Japanese LeisureRelated Values and Behavior.” Journal of Japanese Studies 14 (Summer): 271-307.

Linhart, Sepp and Sabine Frühstück, editors. 1998. The Culture of Japan as Seen through Its Leisure. Albany: State University of New York Press.

McCormack, Gavan. 1996. The Emptiness of Japanese Affluence. Armonk, NY: M.E. Sharpe. Nakamura, Yoshio. 2005. “Income Gap among Japanese Expanding, But Not by Much.” The Japan Times, June 6. Downloaded from <www.japantimes.co.jp/cgi-bin/ makeprfy.p15?nb20050606a1.htm>.

Plath, David W., editor. 1983. Work and Lifecourse in Japan. Albany: State University of New York Press.

. 1964. The After Hours: Modern Japan and the Search for Enjoyment. Berkeley: University of California Press. 
Table 1

Distribution of Working Hours in Japan: 1976-2003

\begin{tabular}{lcccc}
\hline $\begin{array}{l}\text { Regularly Scheduled Hours } \\
\text { per Month }\end{array}$ & $\underline{1976}$ & $\underline{1990}$ & $\underline{1997}$ & $\underline{2003}$ \\
Mean & 162.9 & 155.5 & 145.8 & 141.7 \\
Median & 166.5 & 159.1 & 149.4 & 144.8 \\
$90^{\text {th }}-10^{\text {th }}$ percentile & 9.24 & 11.78 & 9.12 & 10.12 \\
$90^{\text {th }}-50^{\text {th }}$ percentile & 4.00 & 4.52 & 2.76 & 3.54 \\
$50^{\text {th }}-10^{\text {th }}$ percentile & 5.24 & 7.26 & 6.36 & 6.58 \\
\hline $\begin{array}{l}\text { Total Hours per Month } \\
\text { (Scheduled + Non-Scheduled) }\end{array}$ & $\underline{1976}$ & $\underline{1990}$ & $\underline{1997}$ & $\underline{2003}$ \\
Mean & 174.5 & 171.0 & 158.3 & 153.8 \\
Median & 177.1 & 174.1 & 161.5 & 156.8 \\
$90^{\text {th }}-10^{\text {th }}$ percentile & 7.06 & 9.82 & 9.00 & 11.36 \\
$90^{\text {th }}-50^{\text {th }}$ percentile & 3.52 & 2.98 & 2.82 & 3.90 \\
$50^{\text {th }}-10^{\text {th }}$ percentile & 3.54 & 6.84 & 6.18 & 7.46 \\
\hline
\end{tabular}


Table 2

Distribution of Scheduled Working Hours by Earnings Percentiles: 1976-2003

\begin{tabular}{|c|c|c|c|c|c|c|c|c|}
\hline & & \multicolumn{7}{|c|}{ Regularly Scheduled Hours per Month } \\
\hline & & $\underline{1976}$ & & $\underline{1990}$ & & $\underline{1997}$ & & $\underline{2003}$ \\
\hline \multicolumn{2}{|l|}{ Mean } & 162.9 & & 155.5 & & 145.8 & & 141.7 \\
\hline \multicolumn{9}{|c|}{$\begin{array}{c}\text { Regular Contractual Earnings per Month: } \\
\text { Earnings Percentile }\end{array}$} \\
\hline \multicolumn{2}{|l|}{$10^{\text {th }}$} & 172.1 & & 162.7 & & 154.3 & & 148.7 \\
\hline \multicolumn{2}{|l|}{$50^{\text {th }}$} & 171.1 & & 158.5 & & 151.2 & & 138.1 \\
\hline \multicolumn{2}{|l|}{$90^{\text {th }}$} & 160.9 & & 151.6 & & 140.1 & & 138.3 \\
\hline \multicolumn{2}{|c|}{ Ratio of Scheduled Hours } & & $\begin{array}{c}1976- \\
89 \\
\end{array}$ & & $\begin{array}{c}1990- \\
96 \\
\end{array}$ & & $\begin{array}{l}1997- \\
2003 \\
\end{array}$ & \\
\hline $90^{\text {th }} / 10^{\text {th }}$ & $\begin{array}{l}\text { Mean } \\
\text { (Std. Dev.) }\end{array}$ & & $\begin{array}{l}0.952 \\
(0.01)\end{array}$ & & $\begin{array}{l}0.920 \\
(0.01)\end{array}$ & & $\begin{array}{l}0.948 \\
(0.03)\end{array}$ & \\
\hline $90^{\text {th }} / 50^{\text {th }}$ & $\begin{array}{l}\text { Mean } \\
\text { (Std. Dev.) }\end{array}$ & & $\begin{array}{l}0.964 \\
(0.02)\end{array}$ & & $\begin{array}{l}0.940 \\
(0.01)\end{array}$ & & $\begin{array}{l}0.971 \\
(0.02)\end{array}$ & \\
\hline $50^{\text {th }} / 10^{\text {th }}$ & $\begin{array}{c}\text { Mean } \\
\text { (Std. Dev.) }\end{array}$ & & $\begin{array}{l}0.987 \\
(0.02)\end{array}$ & & $\begin{array}{l}0.979 \\
(0.01)\end{array}$ & & $\begin{array}{l}0.976 \\
(0.02)\end{array}$ & \\
\hline
\end{tabular}


Table 3

Distribution of Total Working Hours by Earnings Percentiles: 1976-2003

\begin{tabular}{|c|c|c|c|c|c|c|c|c|}
\hline & & \multicolumn{7}{|c|}{ Total Working Hours per Month } \\
\hline & & $\underline{1976}$ & & $\underline{1990}$ & & $\underline{1997}$ & & $\underline{2003}$ \\
\hline \multicolumn{2}{|l|}{ Mean } & 174.5 & & 171.0 & \multicolumn{3}{|c|}{158.3} & 153.8 \\
\hline \multicolumn{9}{|c|}{$\begin{array}{c}\text { Regular Contractual Earnings per Month: } \\
\text { Earnings Percentile }\end{array}$} \\
\hline \multicolumn{2}{|l|}{$10^{\text {th }}$} & 180.3 & \multicolumn{3}{|c|}{177.2} & \multicolumn{2}{|l|}{166.5} & 158.8 \\
\hline \multicolumn{2}{|l|}{$50^{\text {th }}$} & 182.3 & \multicolumn{3}{|c|}{171.7} & \multicolumn{2}{|l|}{161.8} & 149.1 \\
\hline \multicolumn{2}{|l|}{$90^{\text {th }}$} & 171.6 & \multicolumn{3}{|c|}{167.3} & \multicolumn{2}{|l|}{151.6} & 149.5 \\
\hline \multicolumn{2}{|c|}{ Ratio of Total Hours } & \multicolumn{3}{|c|}{$\begin{array}{l}1976- \\
89 \\
\end{array}$} & $\begin{array}{l}1990- \\
96 \\
\end{array}$ & \multicolumn{3}{|c|}{$\begin{array}{l}1997- \\
2003 \\
\end{array}$} \\
\hline $90^{\text {th }} / 10^{\text {th }}$ & $\begin{array}{l}\text { Mean } \\
\text { (Std. Dev.) }\end{array}$ & \multicolumn{2}{|r|}{$\begin{array}{l}0.974 \\
(0.02)\end{array}$} & & $\begin{array}{l}0.932 \\
(0.01)\end{array}$ & \multicolumn{3}{|c|}{$\begin{array}{l}0.958 \\
(0.03)\end{array}$} \\
\hline $90^{\text {th }} / 50^{\text {th }}$ & $\begin{array}{l}\text { Mean } \\
\text { (Std. Dev.) }\end{array}$ & \multicolumn{2}{|r|}{$\begin{array}{l}0.978 \\
(0.02)\end{array}$} & & $\begin{array}{l}0.948 \\
(0.01)\end{array}$ & \multicolumn{3}{|c|}{$\begin{array}{l}0.982 \\
(0.02)\end{array}$} \\
\hline $50^{\text {th }} / 10^{\text {th }}$ & $\begin{array}{c}\text { Mean } \\
\text { (Std. Dev.) }\end{array}$ & \multicolumn{2}{|r|}{$\begin{array}{l}0.997 \\
(0.02)\end{array}$} & & $\begin{array}{l}0.983 \\
(0.01)\end{array}$ & \multicolumn{2}{|r|}{$\begin{array}{l}0.976 \\
(0.02)\end{array}$} & \\
\hline
\end{tabular}


Table 4

Factors Affecting Hours Ratios, 1976-2003: Scheduled Hours

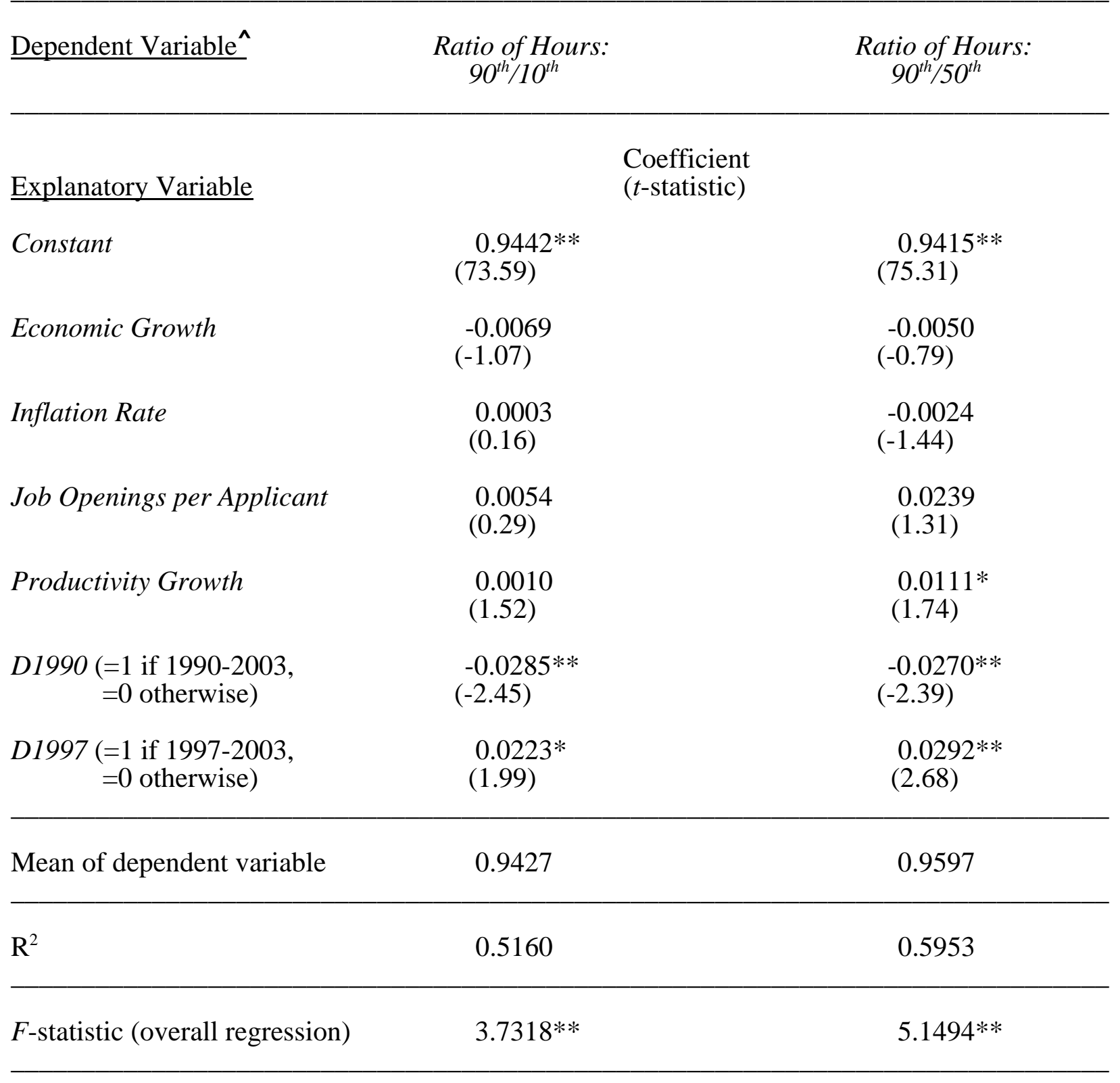

Scheduled hours in the $90^{\text {th }}$ earnings percentile / Scheduled hours in the $10^{\text {th }}$ earnings percentile;

Scheduled hours in the $90^{\text {th }}$ earnings percentile / Scheduled hours in the $50^{\text {th }}$ earnings percentile.

Earnings are regular monthly contractual earnings.

**Significant at the $5 \%$ level.

*Significant at the $10 \%$ level. 
Table 5

Factors Affecting Hours Ratios, 1976-2003: Total Hours

\begin{tabular}{|c|c|c|c|}
\hline Dependent Variable ${ }^{\wedge}$ & $\begin{array}{l}\text { Ratio of Hours: } \\
\quad 90^{\text {th }} / 10^{\text {th }}\end{array}$ & & $\begin{array}{l}\text { Ratio of Hours: } \\
\quad 90^{\text {th }} / 50^{\text {th }}\end{array}$ \\
\hline Explanatory Variable & & $\begin{array}{l}\text { Coefficient } \\
\text { (t-statistic) }\end{array}$ & \\
\hline Constant & $\begin{array}{l}0.9786^{* *} \\
(63.99)\end{array}$ & & $\begin{array}{l}0.9640^{* *} \\
(76.16)\end{array}$ \\
\hline Economic Growth & $\begin{array}{l}-0.0176^{* *} \\
(-2.28)\end{array}$ & & $\begin{array}{l}-0.0117^{*} \\
(-1.83)\end{array}$ \\
\hline Inflation Rate & $\begin{array}{l}-0.0003 \\
(-0.15)\end{array}$ & & $\begin{array}{l}-0.0046^{* *} \\
(-2.77)\end{array}$ \\
\hline Job Openings per Applicant & $\begin{array}{l}0.0106 \\
(0.47)\end{array}$ & & $\begin{array}{l}0.0466^{* *} \\
(2.53)\end{array}$ \\
\hline Productivity Growth & $\begin{array}{l}0.0197 * * \\
(2.52)\end{array}$ & & $\begin{array}{l}0.0143^{* *} \\
(2.21)\end{array}$ \\
\hline $\begin{aligned} D 1990 & (=1 \text { if } 1990-2003, \\
& =0 \text { otherwise })\end{aligned}$ & $\begin{array}{l}-0.0456^{* *} \\
(-3.29)\end{array}$ & & $\begin{array}{l}-0.0499 * * \\
(-4.35)\end{array}$ \\
\hline $\begin{aligned} \text { D1997 } & =1 \text { if } 1997-2003, \\
& =0 \text { otherwise) }\end{aligned}$ & $\begin{array}{l}0.0082 \\
(0.61)\end{array}$ & & $\begin{array}{l}0.0264^{* *} \\
(2.39)\end{array}$ \\
\hline Mean of dependent variable & 0.9595 & & 0.9713 \\
\hline $\mathrm{R}^{2}$ & 0.5946 & & 0.6534 \\
\hline F-statistic (overall regression) & $5.1341 * *$ & & $6.5973 * *$ \\
\hline
\end{tabular}

Total hours in the $90^{\text {th }}$ earnings percentile / Total hours in the $10^{\text {th }}$ earnings percentile;

Total hours in the $90^{\text {th }}$ earnings percentile / Total hours in the $50^{\text {th }}$ earnings percentile.

Earnings are regular monthly contractual earnings.

**Significant at the $5 \%$ level.

*Significant at the $10 \%$ level. 
Figure 1: Hours Ratios in Japan (Scheduled Hours)

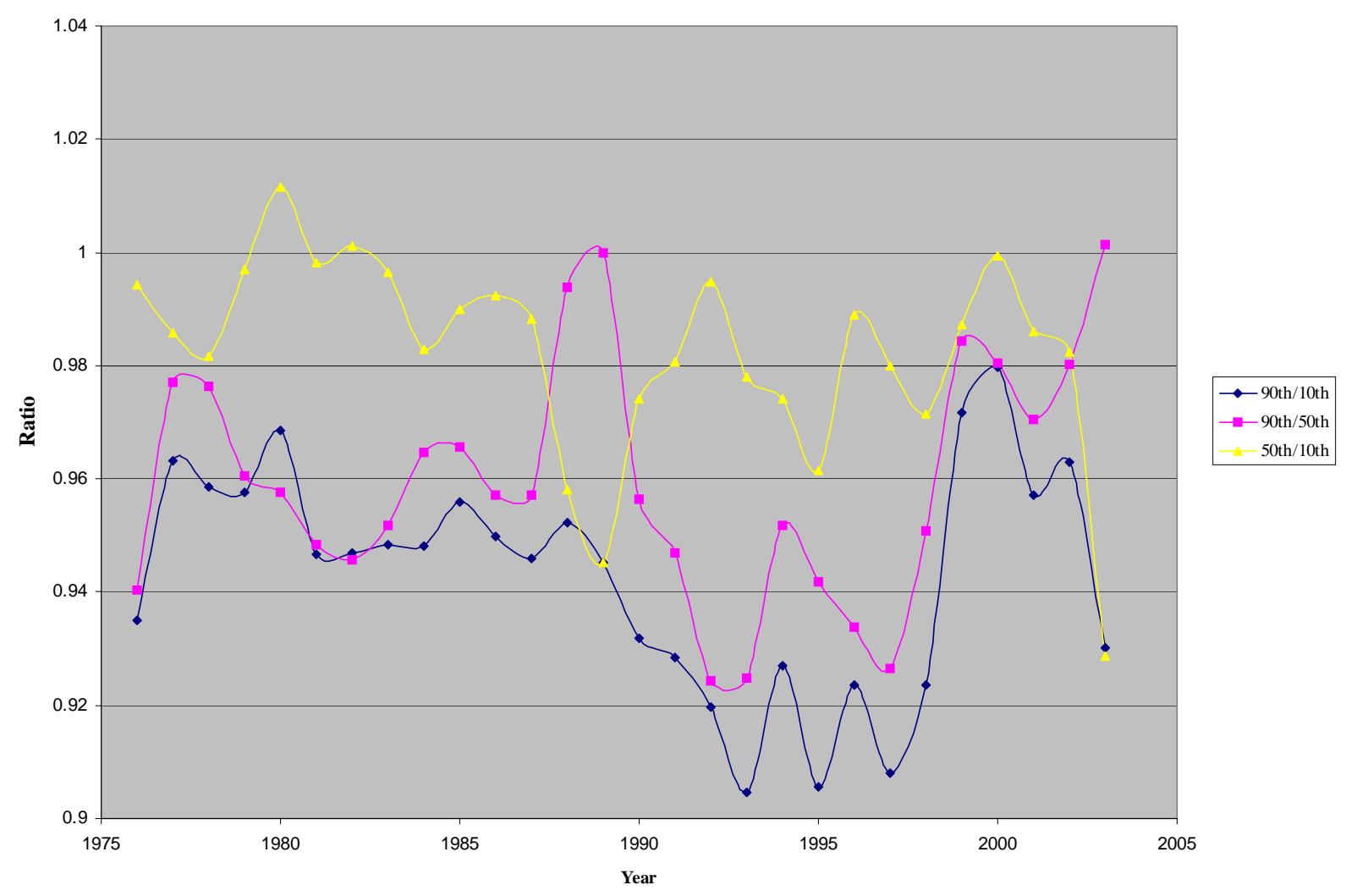


Figure 2: Hours Ratios in Japan (Total Hours)

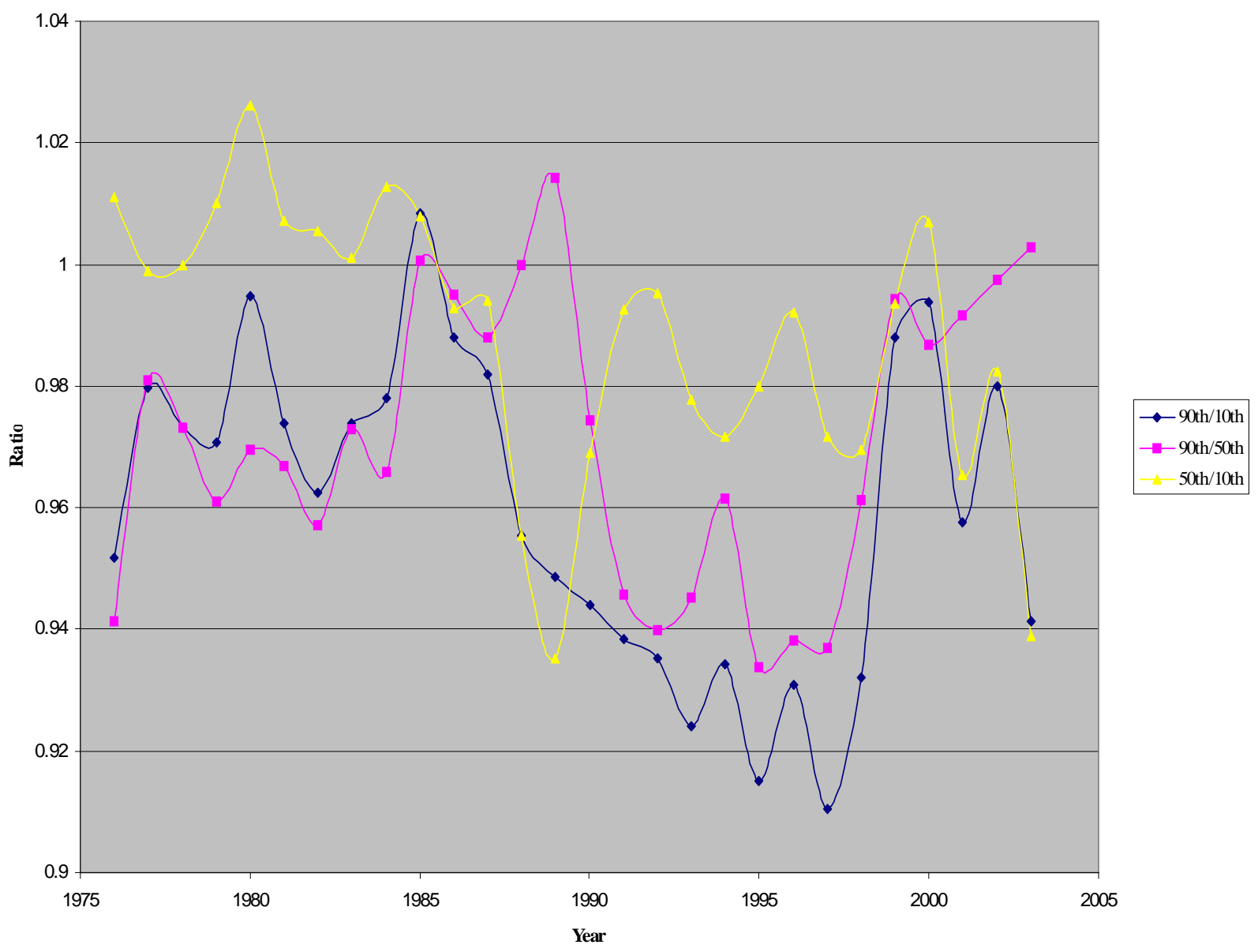

